\title{
Perfluorinated oxygen- and sulfur-containing compounds as extractants for gold(III)
}

\author{
Julia Baker • Robert J. Baker • Carola Schulzke
}

Published online: 9 April 2011

(C) The Author(s) 2011. This article is published with open access at Springerlink.com

\begin{abstract}
A}$ series of highly fluorinated compounds of the type $\left\{\mathrm{CF}_{3}\left(\mathrm{CF}_{2}\right)_{5} \mathrm{CH}_{2} \mathrm{CH}_{2}\right\}_{3} \mathrm{P}=\mathrm{O},\left[\left\{\mathrm{CF}_{3}\left(\mathrm{CF}_{2}\right)_{5} \mathrm{CH}_{2} \mathrm{CH}_{2}\right\}_{2} \mathrm{P}(\mathrm{E})\right.$ $\left.\mathrm{CH}_{2} \mathrm{CH}_{2} \mathrm{P}(\mathrm{E})\left\{\mathrm{CH}_{2} \mathrm{CH}_{2}\left(\mathrm{CF}_{2}\right)_{5} \mathrm{CF}_{3}\right\}\right]$ and $\left\{\mathrm{CF}_{3}\left(\mathrm{CF}_{2}\right)_{5} \mathrm{CH}_{2} \mathrm{CH}_{2}\right\}_{2} \mathrm{C}=\mathrm{E}(\mathrm{E}=\mathrm{O}$ or $\mathrm{S})$ have been examined for their ability to extract gold(III) from aqueous solutions. The phosphine oxides have been studied under liquid-liquid extraction conditions from water into perfluorohexane and found to give poor distribution ratios. The bidentate phosphine oxide, ketone and thioketone were studied under solidliquid extraction conditions and were substantially better with extraction of up to $80 \%$ of $\mathrm{Au}(\mathrm{III})$. In addition, the crystal structure of $\left\{\mathrm{CF}_{3}\left(\mathrm{CF}_{2}\right)_{5} \mathrm{CH}_{2} \mathrm{CH}_{2}\right\}_{3} \mathrm{P}=\mathrm{O}$ has been determined.
\end{abstract}

Keywords Fluorinated ligands - Liquid-liquid extraction . Solid-liquid extraction $\cdot$ E-waste $\cdot$ Crystal structure

\section{Introduction}

Electronic waste (e-waste) has been recognised as one of the fastest growing waste streams in the developed world, mainly due to advances in the electronics industry that render technology obsolete after only a few years $[1,2]$. This can lead to potential environmental problems as a proportion of the waste contains toxic metals such as $\mathrm{Hg}$ (II), $\mathrm{Pb}(\mathrm{II})$ or $\mathrm{Cr}(\mathrm{VI})$. Brominated flame retardants are also widespread in e-waste and there is some concern over the environmental impact of these chemicals [3]. European legislation in the form of the Waste Electrical and Electronic Equipment directive is designed to combat this

J. Baker $\cdot$ R. J. Baker $(\bowtie) \cdot$ C. Schulzke

School of Chemistry, University of Dublin, Trinity College,

Dublin 2, Ireland

e-mail: bakerrj@tcd.ie problem, but its impact has yet to be fully determined. However, these regulations can in principle be used as a framework for a closed loop economy to reclaim commercially valuable metals such as gold, platinum or indium and remove the toxic metals; this has been termed anthropogenic mining [4]. One possible method for removing metals from e-waste is via solvent extraction, but the uses of organic solvents are also subject to legislation pertaining to their safe disposal. Supercritical carbon dioxide $\left(s c \mathrm{CO}_{2}\right)$ has been suggested as a green alternative as it is of low cost and toxicity and available from renewable sources so has been described as green or environmentally benign. However, to extract polar metal cations, a co-extractant has to be added as $\mathrm{CO}_{2}$ has no dipole and hence is a poor solvent. By using conventional solvent extractants such as trioctylphosphine oxide (TOPO) or Cyanex type ligands (in particular phosphine oxides and dialkyl phosphinic acids), $s c \mathrm{CO}_{2}$ extraction of heavy metals from water has been extensively reported [5]. In 1991, Laintz and co-workers reported quantitative studies on the solubilities of metal chelates in $s c \mathrm{CO}_{2}$ and discovered that substituting fluorine into the chelating agent increased the solubility in the supercritical phase by up to three orders of magnitude [6]. This has led to a plethora of ligands designed for homogeneous catalysis, the majority of which are based on modifications of tertiary phosphines [7-9]. Whilst perfluoroalkyl and aryl phosphines have been examined, the corresponding perfluorophosphine oxides have only briefly been described in the literature as intermediates in the synthesis of the phosphines $[10,11]$, and no coordination chemistry has been reported. We have been investigating the use of these perfluorinated analogues of TOPO for extraction of a number of metals and radioisotopes from water into fluorinated solvents $[12,13]$, and the use of perfluorinated phenols for the removal of a number of 
radionuclides from water [14]. We have also exploited the unique solubility properties of fluorous ketones in the removal of a number of heavy metals from water [15]. Herein, we report on the use of the fluorous compounds $\mathrm{Rf}_{3} \mathrm{P}=\mathrm{O}, \mathrm{Rf}_{2} \mathrm{P}(=\mathrm{E}) \mathrm{CH}_{2} \mathrm{CH}_{2} \mathrm{P}(=\mathrm{E}) \mathrm{Rf}_{2}$ and $\mathrm{Rf}_{2} \mathrm{C}=\mathrm{E}(\mathrm{E}=\mathrm{O}$ or $\left.\mathrm{S} ; \mathrm{Rf}=\mathrm{CH}_{2} \mathrm{CH}_{2}\left(\mathrm{CF}_{2}\right)_{5} \mathrm{CF}_{3}\right)$ as extraction agents for gold(III) under liquid-liquid and solid-liquid conditions.

\section{Experimental}

NMR spectra were recorded on a Bruker AV400 spectrometer operating at $400.13\left({ }^{1} \mathrm{H}\right)$ and $376.55\left({ }^{19} \mathrm{~F}\right) \mathrm{MHz}$, and were referenced to the residual ${ }^{1} \mathrm{H}$ resonances of the solvent used or external $\mathrm{CFCl}_{3}$. Infrared spectra were recorded on a Perkin Elmer Spectrum 100 with ATR accessory. Spectrophotometric measurements were recorded on a Thermo Scientific Helios Epsilon spectrometer. A series of known concentrations of gold(III) were measured and from the absorbance at $289 \mathrm{~nm}$, a calibration graph generated $\{[\mathrm{Au}]=$ $\left.\left(\mathrm{A}_{289 \mathrm{~nm}}+0.1018\right) / 0.0072 ; R^{2}=0.9996\right\}$; the limit of detection under these conditions was $11 \mathrm{ppm}$. Inductively coupled plasma (ICP) measurements were recorded on an Agilent 7500a spectrometer, with limits of detection as $1 \mathrm{ppm}$ for $\mathrm{Ag}, \mathrm{As}, \mathrm{Cd}, \mathrm{Cr}, \mathrm{Co}, \mathrm{Fe}, \mathrm{Ga}, \mathrm{Mn}, \mathrm{Ni}, \mathrm{Pb}, \mathrm{Sn}$ and $\mathrm{Tl}$ and $1 \mathrm{ppb}$ for $\mathrm{Hg}$. The errors introduced by the sampling of the phases and other volumetric operations are typically $\pm 3 \%$. Cumulative error including the counting error leads to an experimental average error uniformly taken to be $\pm 5 \%$. The ligands $\left\{\mathrm{CF}_{3}\left(\mathrm{CF}_{2}\right)_{5} \mathrm{CH}_{2} \mathrm{CH}_{2}\right\}_{3} \mathrm{P}=\mathrm{O} \quad[10,11]$, $\left\{\mathrm{CF}_{3}\left(\mathrm{CF}_{2}\right)_{5} \mathrm{CH}_{2} \mathrm{CH}_{2}\right\}_{2} \mathrm{C}=\mathrm{O} \quad\left[\begin{array}{ll}1 & 5\end{array}\right]$ and $\left(\mathrm{CF}_{3}\left(\mathrm{CF}_{2}\right)_{5} \mathrm{CH}_{2} \mathrm{CH}_{2}\right)_{2} \mathrm{P}(=\mathrm{E}) \mathrm{CH}_{2} \mathrm{CH}_{2} \mathrm{P}(=\mathrm{E})$ $\left(\mathrm{CH}_{2} \mathrm{CH}_{2}\left(\mathrm{CF}_{2}\right)_{5} \mathrm{CF}_{3}\right)[12,13]$ were prepared via the literature method. Perfluorohexane (FC-72) was obtained from Acota and distilled before use. All other materials were obtained commercially and used as received.

Preparation of $\left\{\mathrm{CF}_{3}\left(\mathrm{CF}_{2}\right)_{5} \mathrm{CH}_{2} \mathrm{CH}_{2}\right\}_{2} \mathrm{C}=\mathrm{S}$ Lawesson's reagent $(0.36 \mathrm{~g}, 0.84 \mathrm{mmol})$ was added to a suspension of $\left\{\mathrm{CF}_{3}\left(\mathrm{CF}_{2}\right)_{5} \mathrm{CH}_{2} \mathrm{CH}_{2}\right\}_{2} \mathrm{C}=\mathrm{O}(0.60 \mathrm{~g}, 0.83 \mathrm{mmol})$ in THF $\left(10 \mathrm{~cm}^{3}\right)$ and stirred for $12 \mathrm{~h}$ to yield a red solid. This was washed with $\mathrm{Et}_{2} \mathrm{O}$ and dried (11\%). ${ }^{1} \mathrm{H}$ NMR (dmso$\left.\mathrm{d}_{6}\right): 1.58\left(\mathrm{~m}, 6 \mathrm{H}, \mathrm{CH}_{2}\right) 1.28\left(\mathrm{~m}, 6 \mathrm{H}, \mathrm{CH}_{2}\right) ;{ }^{19} \mathrm{~F}$ NMR $\left(\mathrm{dmso}_{6}\right)$ : $-84.3\left(\mathrm{~s}, \mathrm{CF}_{3}\right),-103.4\left(\mathrm{~m}, \mathrm{CF}_{2} \mathrm{CH}_{2}\right),-120.1$ $\left(\mathrm{CF}_{2}\right),-123.1\left(\mathrm{CF}_{2}\right),-126.3\left(\mathrm{CF}_{2}\right),-128.1\left(\mathrm{CF}_{2}\right) ; \mathrm{IR} /$ $\mathrm{cm}^{-1}: 3065(\mathrm{w}), 1634$ (w), 1606 (s), 1486 (s), 1447 (s), 1245 (w), 1216 (m), 1159 (w), 1068 (s), 1043 (s), 1015 (m), $960(\mathrm{w}), 756(\mathrm{~s}), 749(\mathrm{~s}), 638(\mathrm{~s})$.

Liquid-liquid extractions For ligand 1, $5 \mathrm{~cm}^{3}$ of a $200 \mathrm{ppm}$ aqueous solution of $\mathrm{Na}\left[\mathrm{AuCl}_{4}\right]$ was added to a solution of $\mathbf{1}$ in $5 \mathrm{~cm}^{3}$ of FC-72 (Table 1). The mixture was stirred for $30 \mathrm{~min}$, the phases separated and the concentration of gold in the
Table 1 Extraction of $\mathrm{Na}\left[\mathrm{AuCl}_{4}\right]$ using 1 and 2. Conditions: 1:1 FC$72: \mathrm{H}_{2} \mathrm{O}, t=60 \mathrm{~min}, \mathrm{pH}=6, t=30^{\circ} \mathrm{C}$

\begin{tabular}{lclc}
\hline Ligand & Equivalents & $D$ & Percentage extraction \\
\hline 1 & 0 & 0.000 & 0 \\
1 & 0.070 & 5.6 \\
& 2 & 0.059 & 6.5 \\
2 & 0 & 0.000 & 0 \\
& 1 & 0.076 & 7.1 \\
& 2 & 0.584 & 36.9 \\
\hline
\end{tabular}

aqueous solution was determined by spectrometric measurements. For ligand 2, a solution of $\mathrm{NaAuCl}_{4}\left(1 \mathrm{~cm}^{3}\right.$ of a $20 \mathrm{ppm}$ stock solution) was placed in a sample vial and made up to $5 \mathrm{~cm}^{3}$ with a buffer solution of $\mathrm{pH} 6$. The required amount of phosphine oxide was dissolved in $5 \mathrm{~cm}^{3}$ of FC-72 and added to the metal solutions. The mixture was vigorously stirred for $30 \mathrm{~min}$, and the phases were allowed to separate. An aliquot $\left(1 \mathrm{~cm}^{3}\right)$ of the aqueous layer was transferred to a sample tube, diluted to $5 \mathrm{~cm}^{3}$ and analysed by ICP techniques. A $1 \mathrm{~cm}^{3}$ of the stock solution was diluted to $5 \mathrm{~cm}^{3}$ and counted. The amount of gold in the fluorous solution was the difference between this standard and experimentally measured sample. The results presented are an average of three runs.

Solid-liquid extractions A solution of $\mathrm{Na}\left[\mathrm{AuCl}_{4}\right]\left(5 \mathrm{~cm}^{3}\right.$ of a $200 \mathrm{ppm}$ stock solution at $\mathrm{pH}=6$ ) was added to the required solid extractant under the conditions described in Table 2. After vigorous stirring, an aliquot was taken and the gold concentration was determined spectrophotometrically. The results presented are an average of three runs.

\section{Results and discussion}

The reclamation of gold from electronic waste is attractive economically, particularly given the scale of mobile phone,

Table 2 Extraction of $\mathrm{Na}\left[\mathrm{AuCl}_{4}\right]$ using 2-5. Conditions: $5 \mathrm{~cm}^{3} \mathrm{H}_{2} \mathrm{O}$, $\mathrm{pH}=6,[\mathrm{Au}]_{0}=200 \mathrm{ppm}, t=30^{\circ} \mathrm{C}$

\begin{tabular}{lccc}
\hline Ligand & Time (min) & {$[\mathrm{Au}]_{\mathrm{t}}$ ccppm) } & Percentage extraction \\
\hline 2 & 30 & 91.13 & 54.4 \\
& 60 & 48.87 & 75.6 \\
3 & 30 & 196.20 & 1.9 \\
& 60 & 188.59 & 5.7 \\
4 & 30 & 31.41 & 84.3 \\
& 60 & 20.00 & 90.0 \\
5 & 30 & 190.85 & 4.6 \\
& 60 & 93.38 & 53.3 \\
\hline
\end{tabular}


PC and printed circuit boards being disposed of each year. Estimates for 2005 put this at 555 tonnes of gold, or 3\% of the world mine supply [16]. Current commercial reclamation of gold is carried out via smelting and other hydrometallurgical procedures or cyanide leaching [17]. Obviously, a less energy intensive or toxic procedure would be a useful addition to the current technologies. In this contribution, we report on the use of a series of highly fluorinated compounds 1-5 as liquid-liquid (compounds $\mathbf{1}$ and 2) or solid-liquid (compounds 2-5) extractants for $\mathrm{Na}$ [AuCl$]_{4}$ (Fig. 1).

Liquid-liquid extractions In our previous studies, we have used FC-72 as a model for $s c \mathrm{CO}_{2}$. Perfluorinated solvents have many similar properties to supercritical solvents but with the advantage that pressure apparatus is not required, allowing extractants to be screened and optimised more readily. Importantly, perfluorophosphine-containing complexes have been previously demonstrated to have similar solubility in both fluorous and $s c \mathrm{CO}_{2}$ solvents [18]. A solution of $\mathbf{1}$ in FC-72 was added to an aqueous solution of $\mathrm{Na}\left[\mathrm{AuCl}_{4}\right]$ and stirred vigorously for $1 \mathrm{~h}$. After separation of the phases, the aqueous phase was analysed by either ICPOES or spectrophotometrically. The reaction was examined with one and two equivalents of ligands $\mathbf{1}$ and $\mathbf{2}$ shown in Table 1; the distribution ratio is defined as $D=[\mathrm{Au}]_{\mathrm{f}} /[\mathrm{Au}]_{\mathrm{aq}}$. When no ligand is present, we observe no gold in the fluorous layer.

Both ligands are rather poor at extracting gold(III) from aqueous solutions into FC-72. This is in contrast to that reported for TOPO [19] and other Cyanex extractants [2023] which are capable of almost quantitative extraction of gold(III) into organic solvents. For ligand 1, the variation of $\log D$ vs. $\log [L]$ was examined in order to determine the number of ligands coordinated to the extractable gold species. The results are shown in Fig. 2 and the gradient of 0.5 implies that the extractable species contains two gold for every one ligand. Again, this is in contrast to the reported data for TOPO which extracts as a one to one complex. However, given the disappointing distribution ratios, liquid-liquid extractions were not examined further.

Single crystals of 1 suitable for X-ray diffraction were grown from hot dichloromethane, but the structure could not be refined to give an accurate description of the metric

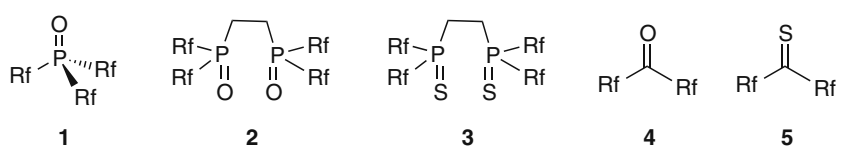

Fig. 1 Structures of the extractants relevant to this study; $\mathrm{Rf}=$ $\mathrm{CH}_{2} \mathrm{CH}_{2}\left(\mathrm{CF}_{2}\right)_{5} \mathrm{CF}_{3}$

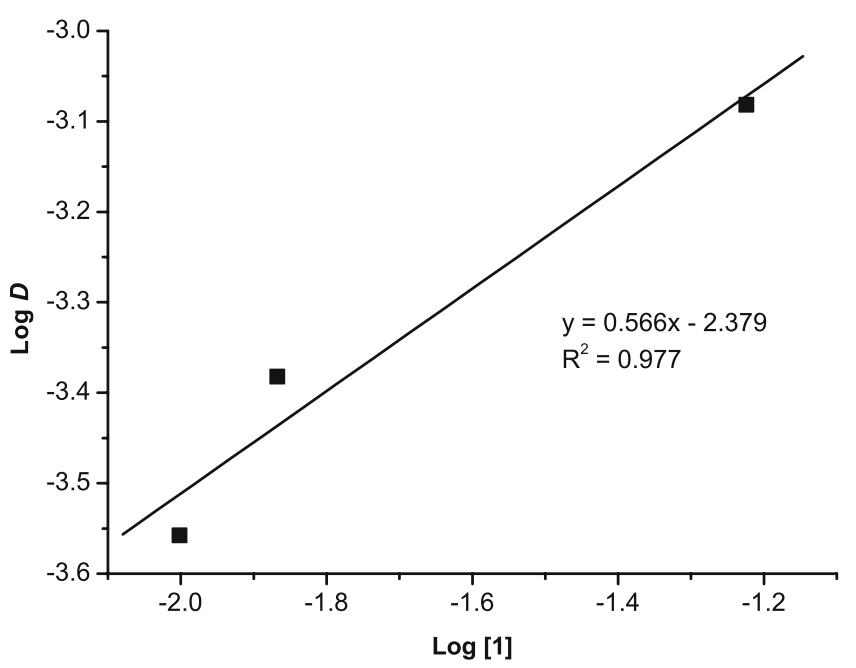

Fig. 2 Plot of $\log D$ vs. $\log [L]$ for complex 1. Conditions: $[\mathrm{Au}]_{0}=$ $200 \mathrm{ppm} ; 1: 1 \mathrm{FC}-72: \mathrm{H}_{2} \mathrm{O}, t=30 \mathrm{~min}, \mathrm{pH}=6, t=30^{\circ} \mathrm{C}$

parameters $\left(R_{1}=0.1817(\mathrm{I}>2 \sigma(\mathrm{I})) ; \mathrm{wR}_{2}(\right.$ all data $\left.)=0.4116\right)$ [24]. However, the packing of $\mathbf{1}$ is of interest and shown in Fig. 3. The fluorous chains give a " $T$ " shape to the molecule and the packing is such that fluorous-fluorous interactions are maximised. The packing motif is similar to that of the phosphine $\mathrm{P}\left(\mathrm{CH}_{2} \mathrm{CH}_{2} \mathrm{CH}_{2}\left(\mathrm{CF}_{2}\right)_{7} \mathrm{CF}_{3}\right)_{3}$ [11]. Additional interactions between the oxygen and hydrogen of a second molecule are also present that form infinite stacks along the $\mathrm{P}=\mathrm{O}$ vector. These hydrogen bonds would be expected to be reasonably strong as the $\mathrm{CF}_{2}$ chain would polarise the $\mathrm{C}-\mathrm{H}$ function, making it a better $\mathrm{H}$-bond donor and that $\mathrm{P}=\mathrm{O}$ is a good acceptor. We are investigating this using computational chemistry and the results will reported in due course. From this discussion, we can now postulate the nature of the extractable species. It is known that the speciation of $\left[\mathrm{AuCl}_{4}\right]^{-}$in weakly acidic solution is $\left[\mathrm{AuCl}_{3}(\mathrm{OH})\right]^{-}$or $\left[\mathrm{AuCl}_{2}(\mathrm{OH})_{2}\right]^{-}$[25-28], so we suggest that the 2:1 extractable species is formed by hydrogen bonding from the phosphine oxide to the $\mathrm{OH}$ group on two gold complexes. Multiple H-bond acceptors on phosphine oxides have been reported [29]. Furthermore, the poor extraction using thiophosphines (vide infra), which are poor $\mathrm{H}$-bond acceptors, also suggest that hydrogen bonding is important, and direct coordination to the gold centre does not play a role.

Solid-liquid extractions One of the drawbacks in the liquid-liquid methodology described above is the use of fluorinated solvents, which are typically expensive and have a detrimental environmental impact. We have therefore examined the suitability of these in solid phaseaqueous phase extractions. Compound 2, whilst soluble in FC-72 does not have high solubility in organic solvents. We have previously reported on the synthesis of the sulfur 
Fig. 3 Packing diagram of 1

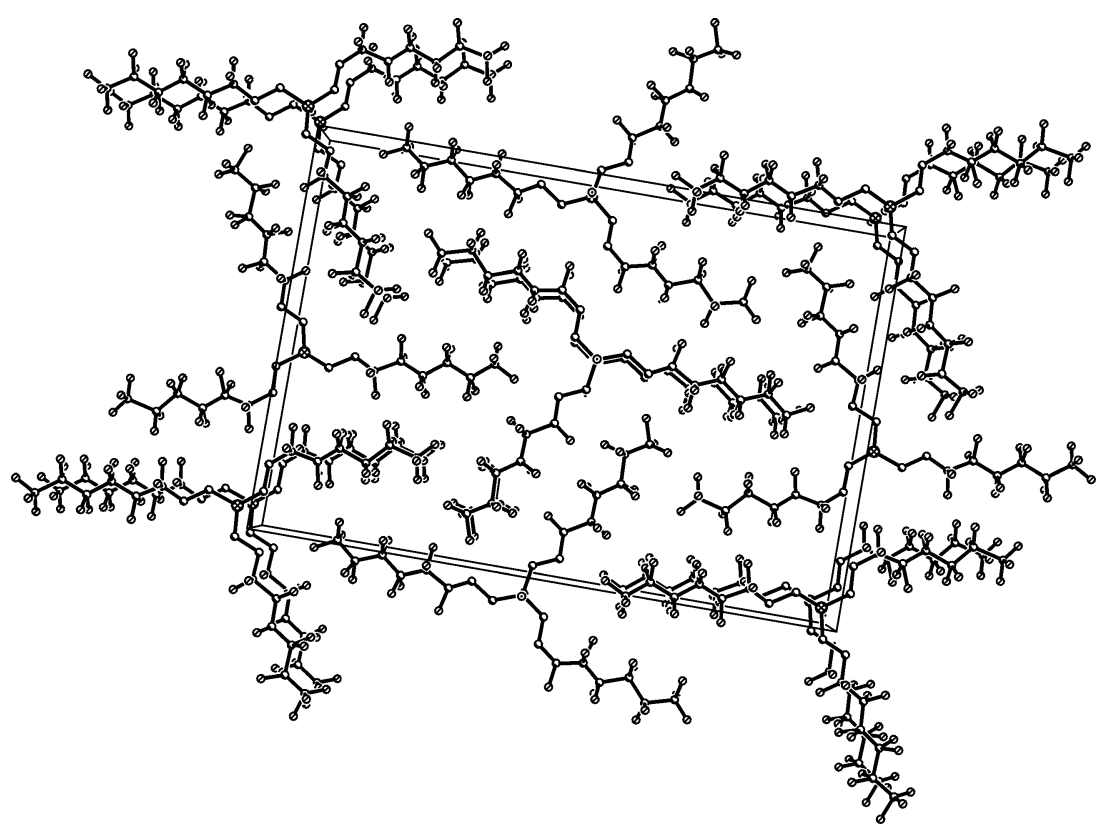

analogue, 3, and this displays almost no solubility in any organic or fluorous solvent $[12,13]$. We have previously shown the utility of $\mathbf{4}$ in extracting a series of metals from aqueous solution under solid phase-liquid phase conditions, and the sulfur analogue would be of interest in gold extractions as it is a softer donor. Thus, $\mathbf{4}$ can be converted into 5 by treatment with Lawesson's reagent in rather poor yield; whilst variable yields have been reported for Lawesson's [30], we believe that poor solubility is the reason for the low yield. Attempts to repeat the reaction with $\mathrm{P}_{4} \mathrm{~S}_{10}$ also gave low yield and a more difficult work-up. As has been previously observed for $\mathbf{3}, \mathbf{5}$ shows very limited solubility in organic and fluorous solvents, which has hampered full characterisation. However, infrared spectroscopy shows the loss of $v(\mathrm{C}=\mathrm{O})$ band at $1,724 \mathrm{~cm}^{-1}$ and the presence of $v(\mathrm{C}=\mathrm{S})$ at $1,043 \mathrm{~cm}^{-1}$. Compounds 2-5 were expected to coordinate to the gold(III) compounds in solution and remove them by precipitation. As can be seen from the results presented in Table 2, the oxygen donor ligands are substantially better at removing gold(III) from solution compared to the $\mathrm{P}=\mathrm{S}$ and $\mathrm{C}=\mathrm{S}$ ligands. We examined the dependence of the extraction upon time for 2-5 and found that maximum extraction was observed after $1 \mathrm{~h}$. For compound 2, we also examined the $\mathrm{pH}$ dependence but surprisingly found that under any acidic $\mathrm{pH}$, there was no significant change in extraction efficiency; under alkaline conditions $\mathrm{Na}\left[\mathrm{AuCl}_{4}\right]$ is known to form hydroxides or oxides [31] and this was not investigated. The infrared spectrum of the precipitate obtained from 4 showed a shift in the $v(\mathrm{C}=\mathrm{O})$ band from $1,724 \mathrm{~cm}^{-1}$ to $1,608 \mathrm{~cm}^{-1}$, similar to that seen for coordination to $\operatorname{Sn}(\mathrm{II})\left(1,599 \mathrm{~cm}^{-1}\right)$ [15] and indicative of oxygen coordination.
Finally, in order to ascertain the applicability of these new extractants towards the plethora of metals expected in e-waste, we have examined $\mathbf{4}$ as an extractant for a series of metals in solution and the results are shown in Fig. 4; Cd, $\mathrm{Pb}, \mathrm{As}, \mathrm{Sn}$ and $\mathrm{Hg}$ have previously been reported [15]. Interestingly, $\mathbf{4}$ does not extract iron(III), but other metals that are commonly found in printed circuit boards, mobile phones and PCs are extracted to a reasonable extent. In particular, silver is quantitatively removed (within the limits of detection). Recent reports have shown that $\mathrm{Ag}^{+}$can be extracted into $\mathrm{scCO}_{2}$ using CYANEX 301 with $92 \%$ extraction [32].

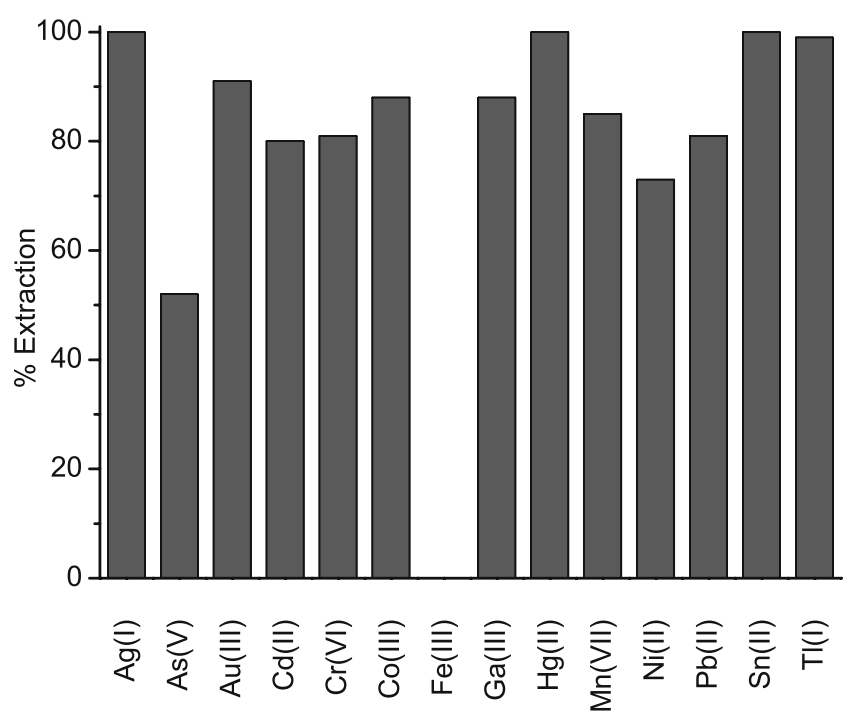

Fig. 4 Extraction of a series of metals using 4 
In conclusion, we have shown that highly fluorinated $\mathrm{P}=\mathrm{O}$ and $\mathrm{C}=\mathrm{O}$ ligands are effective extraction agents under solid-liquid extraction conditions for gold(III) and can be extended to other metals of interest in e-waste. Further work will extend our study towards the development of solid supports for the fluorous ligands.

Acknowledgement We thank Trinity College Dublin for funding this work and the Centre for Microscopy and Analysis at TCD for ICP measurements.

Open Access This article is distributed under the terms of the Creative Commons Attribution License which permits any use, distribution, and reproduction in any medium, provided the original author(s) and source are credited.

\section{References}

1. Chancerel P, Meskers CEM, Hagelüken C, Rotter VS (2009) J Ind Ecol 13:791

2. Robinson BH (2009) Sci Total Environ 408:183

3. Birnbaum LS, Staskal DF (2004) Environ Health Perspect 112:9

4. Johnson J, Harper EM, Lifset R, Graedel TE (2007) Environ Sci Technol 41:1759

5. Erkey C (2000) J Supercrit Fluids 17:259

6. Laintz KE, Wai CM, Yonker CR, Smith RD (1991) J Supercrit Fluids 4:194

7. Hope EG, Stuart AM (2004) Handbook of fluorous chemistry. Wiley, Weinheim

8. Banger KK, Brisdon AK, Herbert CJ, Ghaba HA, Tidmarsh IS (2009) J Fluorine Chem 130:1117

9. Gudmunsen D, Hope EG, Paige DR, Stuart AM (2009) J Fluorine Chem 130:942

10. Vlád G, Richter FU, Horváth IT (2005) Tett Lett 46:8605

11. Alvey LJ, Rutherford D, Juliette JJJ, Gladysz JA (1998) J Org Chem 63:6302
12. Baker RJ, Ogilvie HV, WO2009109754A1

13. Baker RJ, Fuchs J, Richards AJ, Ogilvie HV (2011) J Environ Manage, in press

14. Baker RJ, Ogilvie HV, Richards AJ (2010) Radiochim Acta 98:507

15. Baker RJ, McCabe T, O'Brien JE, Ogilvie HV (2010) J Fluorine Chem 131:621

16. Hagelüken C, Corti CW (2010) Gold Bull 43:209, and references therein

17. Marsden J, House I (1992) The chemistry of gold extraction. Ellis Horwood, Chichester

18. Stribrany RT, Gorun SM (1999) J Organomet Chem 579:217

19. Martínez S, Sastre A, Alguacil FJ (1997) Hydrometallurgy 46:205

20. Alguacil FJ (2004) Hydrometallurgy 71:363

21. Barroso MA, López FA, Sastre A, Alguacil FJ (1997) Hydrometallurgy 45:199

22. Martínez S, Navarro P, Sastre AM, Alguacil FJ (1996) Hydrometallurgy 43:1

23. Martínez S, Sastre A, Miralles N, Alguacil FJ (1996) Hydrometallurgy 40:77

24. Key Data: $150 \mathrm{~K}$, Orthorhombic, $\mathrm{P} 2{ }_{1} 2{ }_{1} 2, Z=4$, unit cell $\alpha=5.172$ $\AA, \beta=21.675 \AA, \gamma=31.554 \AA$; reflections collected: 31056 ; unique reflections: $7346 ; R$ (int) $=0.2627 ; R_{1}=0.1817(\mathrm{I}>2 \sigma(\mathrm{I})) ; \mathrm{wR}_{2}$ (all data) $=0.4116$; GOOF: 1.050

25. Usher A, McPhail DC, Brugger J (2009) Geochim Cosmochim Acta 73:3359

26. Chen X, Chu W, Chen D, Wu Z, Marcelli A, Wu Z (2009) Chem Geol 268:74

27. Murphy PJ, Lagrange MS (1998) Geochim Cosmochim Acta 62:3515

28. Arces F, Sharps JA, Brown GE Jr (1993) Geochim Cosmochim Acta 57:1243

29. Durrell AC, Gray HB, Hazari N, Incarvito CD, Liu J, Yan ECY (2010) Cryst Growth Des 10:1482

30. Ozturk T, Ertas E, Mert O (2007) Chem Rev 107:5210

31. Cotton FA, Wilkinson G, Murillo CA, Bochmann M (1999) Advanced inorganic chemistry, 6th Edn. Wiley

32. Pourmortazavi SM, Hajimirsadeghi SS, Kohsari I, Hosseini SG (2004) J Chem Eng Data 49:1530 